UDC 678.686

\author{
K.M. Sukhyy ${ }^{a}$, E.A. Belyanovskaya ${ }^{a}$, A.N. Nosova ${ }^{a}$, M.K. Sukhyy ${ }^{a}$, V.P. Kryshen ${ }^{b}$, \\ Y. Huang ${ }^{c}$, Yu. Kocherhin ${ }^{c}$, T. Hryhorenko ${ }^{c}$
}

\title{
PROPERTIES OF EPOXY-THIOKOL MATERIALS BASED ON THE PRODUCTS OF THE PRELIMINARY REACTION OF THIOETHERIFICATION
}

\author{
a Ukrainian State University of Chemical Technology, Dnipro, Ukraine \\ ${ }^{b}$ Dnipro State Medical University, Dnipro, Ukraine \\ ${ }^{c}$ Harbin Institute of Technology, Harbin, People's Republic of China
}

\begin{abstract}
In order to improve the adhesive and physical-mechanical properties of epoxy-thiocol compositions cured without heat treatment, we propose to carry out the reaction of interaction between thiokol mercaptan groups and oxirane cycles of epoxy resin at an elevated temperature before introducing a curing agent, and then use the product of this thioetherification reaction for curing at room temperature. The temperature range of the thioetherification reaction $\left(90-180^{\circ} \mathrm{C}\right)$ was determined by the method of differential scanning calorimetry. The optimal temperature $\left(160^{\circ} \mathrm{C}\right)$ and duration of the preliminary thioetherification reaction ( 2 hours) were determined, which ensure the maximum level of adhesive strength and physical-mechanical properties. It was shown that composite materials based on the products of the thioetherification reaction significantly outperform analogs based on mechanical mixtures of epoxy resin and thiokol in terms of cohesive and adhesive strength, deformation capacity, fracture work and specific impact strength. The impact resistance and shear strength of adhesive joints are especially significantly increased during the curing of the compositions without external heat supply.
\end{abstract}

Keywords: epoxy resin, thiokol, thioetherification reaction, adhesive and cohesive properties, mechanical mixture, differential scanning calorimetry.

DOI: $10.32434 / 0321-4095-2021-136-3-128-136$

\section{Introduction}

At the present time, epoxypolymers (EP) came into sharp focus as a special class of materials with unusually wide possibilities of application due to their specific and, moreover, almost universal properties:

- low viscosity, especially in combination with active thinners, plasticizers and hardeners;

- the ability to solidify at room temperature, and at low temperatures when catalysts used;

- minimal shrinkage during solidifying, which ensures a low level of internal stresses in coatings based on them;

- excellent adhesion to various materials (metals, concrete, glass, stone and others) combined with a high range of physical and mechanical properties;

- good anti-corrosion characteristics, which result from the presence in the structure of their molecules of epoxy, hydroxyl and ether groups, as well as aromatic rings;

- high electrical insulating properties, etc.

Despite the aforementioned advantages of EP, their significant disadvantages are low shock, vibration and crack resistance, which sharply limits their use under the action of dynamic loads and thermal cycles. Currently, there are various ways to overcome these disadvantages [1-6].

The most promising way to improve the working capacity of epoxy materials under the action of these operational factors is the modification of EP with liquid rubbers, which are copolymers of oligobutadiene and acrylonitrile with terminal carboxyl groups [7]. Thus, the use of these rubbers in epoxy adhesives made it possible to increase the static adhesive strength from $\sim 10$ to $24-30 \mathrm{MPa}$ and the dynamic strength of the adhesive bonding by 3-5 times [8]. Distinctive features of the given adhesives are the low dependence of properties on

(C) K.M. Sukhyy, E.A. Belyanovskaya, A.N. Nosova, M.K. Sukhyy, V.P. Kryshen, Y. Huang, Yu. Kocherhin, T. Hryhorenko, 2021

K.M. Sukhyy, E.A. Belyanovskaya, A.N. Nosova, M.K. Sukhyy, V.P. Kryshen, Y. Huang, Yu. Kocherhin, T. Hryhorenko 
the concentration and chemical nature of the hardener, cure temperature, influence of temperature gradients, vibrations, water and other aggressive media. At the same time, taking into account the high cost of carboxylate rubbers, the problem of replacing them with cheaper and more affordable ones still remains urgent. In this regard, polysulfide rubbers are of great interest. Apart from the fact that they are almost 2.5 times cheaper than carboxylate ones, they are also more convenient in production due to their lower viscosity and better thermodynamic compatibility with epoxy resin.

In addition, it should be noted that at present time there is a surplus of sulfur formed during the processing of constantly increasing volumes of sulfurcontaining hydrocarbons (oil, gas) and deeper purification from sulfur of oil refinery products, waste and flue gases of coke-chemical, metallurgical and energy industries because of tightening requirements for environmental protection. In this situation, there is a crucial problem of developing new researchintensive sulfur-containing materials, the price of which will significantly exceed the price of sulfur itself as a raw material, and expanding the use of sulfur in non-traditional material-intensive areas. To date, a certain amount of experience has been gained in using thiokol for modifying EP. The main attention in very numerous studies, actively carried out over a long period of time (from the 1960s to the present), was paid to the creation of sealing materials which do not have strict requirements for adhesive and cohesive strength, resistance to aggressive media and other parameters, such as physical and mechanical properties [9-11]. In such systems, the role of the matrix that determines the structure and basic operational properties of the material is played by a chemical network formed by thiokol and a curative. The introduction of a small additive (up to 30 mass parts) of epoxy resin (ER) into this matrix helps to increase the adhesion of thiokol sealants to various substrates.

In the case of epoxy materials, especially for structural purposes, the characteristics of adhesion and mechanical strength, resistance to shock and vibration loads, temperature changes, water and chemical resistance become of crucial importance. In this regard, taking into account the high mechanical properties, chemical resistance, and good adhesion to many materials, it seems appropriate to use EP as a matrix, and take thiokol as a modifying additive that increases the adhesive strength and shock resistance of the matrix.

It was found (which should be expected a priori) that the effect of increasing the adhesion strength and work of destruction for thiokols is much less exhibited than for carboxylate rubbers [12].

Since the terminal $\mathrm{SH}$-groups of the thiokol are capable of interacting with the terminal oxirane rings of the epoxy resin, it was of undoubted interest, as in the case of carboxyl rubbers, to carry out a preliminary reaction of the interaction of the terminal groups of the thiokol and ES according to the scheme:

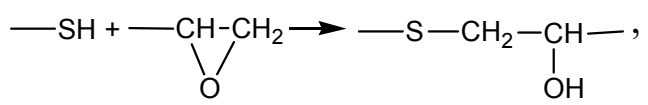

and further investigate the properties of compositions based on the products of this reaction of thioetherification. In this regard, it was of doubtless interest to carry out overall studies of the effect of polysulfide rubber in a wide range of concentrations on the deformation-strength, relaxation and adhesion parameters of epoxy polymers, which determine their basic operational properties.

\section{Experimental}

The object of study is epoxy-diane resin of Epikote- 828 brand with a mass fraction of epoxy groups of $22.8 \%$, a molecular weight of 380 and a dynamic viscosity of $12.5 \mathrm{~Pa} \cdot \mathrm{s}$. The polysulfide rubber used was a liquid thiokol brand I of the following formula:

$\left.\mathrm{SH}+\mathrm{C}_{2} \mathrm{H}_{4}-\mathrm{O}-\mathrm{CH}_{2}-\mathrm{O}-\mathrm{C}_{2} \mathrm{H}_{4}-\mathrm{S}-\mathrm{S}\right)_{\mathrm{n}} \mathrm{C}_{2} \mathrm{H}_{4}-\mathrm{O}-\mathrm{CH}_{3}$,

where $n=6-23$. Its viscosity at $25^{\circ} \mathrm{C}$ is $28 \mathrm{~Pa} \cdot \mathrm{s}$ and the content of sulfhydryl groups is $3.1 \%$. hardener.

Diethylenetriamine DETA was used as a

Compositions were solidified according to the following modes:

- cold hardening: $(20 \pm 2)^{\circ} \mathrm{C} / 240 \mathrm{~h}$ (mode I);

- hardening with heat treatment: $(20 \pm 2)^{\circ} \mathrm{C} / 24 \mathrm{~h}+120^{\circ} \mathrm{C} / 3 \mathrm{~h}$ (mode II).

The following research methods were used.

Heat effect of reaction, temperature of beginning reaction and temperature of maximal rate of reaction were determined on a DSC unit of the Du Pont 9900 thermoanalytical complex. A sample of $\sim 10 \mathrm{mg}$ was heated to $230^{\circ} \mathrm{C}$ at the rate of $10^{\circ} \mathrm{C} / \mathrm{min}$.

The mechanical properties of film samples with the thickness of $\sim 150 \mathrm{~mm}$ under uniaxial tension (breaking stress $\sigma_{\mathrm{t}}$ and deformation at break $\varepsilon_{\mathrm{s}}$ ) were determined by a Polyany-type device with a rigid dynamometer and automatic recording of measured values [13]. The elastic modulus (E) was calculated from the slope of the initial portion of the $\sigma$ vs. $\varepsilon$ curve. The area under the stress-strain curve $\sigma$ vs. $\varepsilon$ served as a measure of the work of destruction $\left(A_{p}\right)$. 
Films with a thickness of $100-150 \mu \mathrm{m}$ were obtained by hardening polymer composites between two polished surfaces of metal plates coated with a thin layer of a release agent. Shear adhesion strength $\left(\tau_{\mathrm{sh}}\right)$ was determined according to the State Standard 14759-69.

Water absorption (W) was determined by the change in the mass of the samples after boiling for 3 hours according to the following formula:

$$
\mathrm{W}(\mathrm{t})=\frac{\mathrm{m}(\mathrm{t})-\mathrm{m}_{0}}{\mathrm{~m}_{0}} \cdot 100 \%,
$$

where $\mathrm{m}_{0}$ is the initial mass of the sample; $\mathrm{m}(\mathrm{t})$ refers to the mass of the sample after immersion in the water during time $t$.

The abrasion index (I) was determined according to the State Standard 11012-2017 on an APGI machine (Germany). The essence of the method is to determine the decrease in the volume of the sample in cubic millimeters as a result of abrasion (wear) per $1 \mathrm{~m}$ of the abrasion path with a grinding cloth. The load on the sample was $1 \mathrm{~kg}$, the length of the abrasion path of the sample was $10 \mathrm{~m}$ ( 25 revolutions of the machine cylinder).

The density of the samples $(\rho)$ was measured by the gradient column method according to the State Standard 15139-69.

The molecular weight of the chain section between the nodes of the chemical network $\left(M_{c}\right)$ was calculated from the value of the equilibrium dynamic elastic modulus E' measured at a temperature $\mathrm{T}=\mathrm{T}_{\mathrm{c}}+50^{\circ} \mathrm{C}$ using the following formula:

$$
\mathrm{M}_{\mathrm{C}}=\frac{3 \rho \mathrm{RT}}{\mathrm{E}^{\prime}}
$$

where $\mathrm{R}$ is the universal gas constant; $\mathrm{T}$ is the absolute temperature; $\rho$ is the density of a polymer.

Density of joints of chemical network $\left(n_{c}\right)$ is calculated by the formula:

$$
\mathrm{n}_{\mathrm{C}}=\frac{\rho}{\mathrm{M}_{\mathrm{C}}} \text {. }
$$

Compression strength $\left(\sigma_{\mathrm{c}}\right)$ is determined according to the State Standard 4651-2014 (ISO 604:2002), specific impact viscosity being measured by ISO 179-1:2010. Bend strength is determined by the State Standard 4648-2014 (ISO 178:2010).

\section{Results and discussion}

Differential scanning calorimetry (DSC) was used to determine the temperature range of the reaction between epoxy resin and thiokol. As evidenced by the data of Table 1 and Fig. 1, this interaction occurs in a wide temperature range of $80-180^{\circ} \mathrm{C}$.

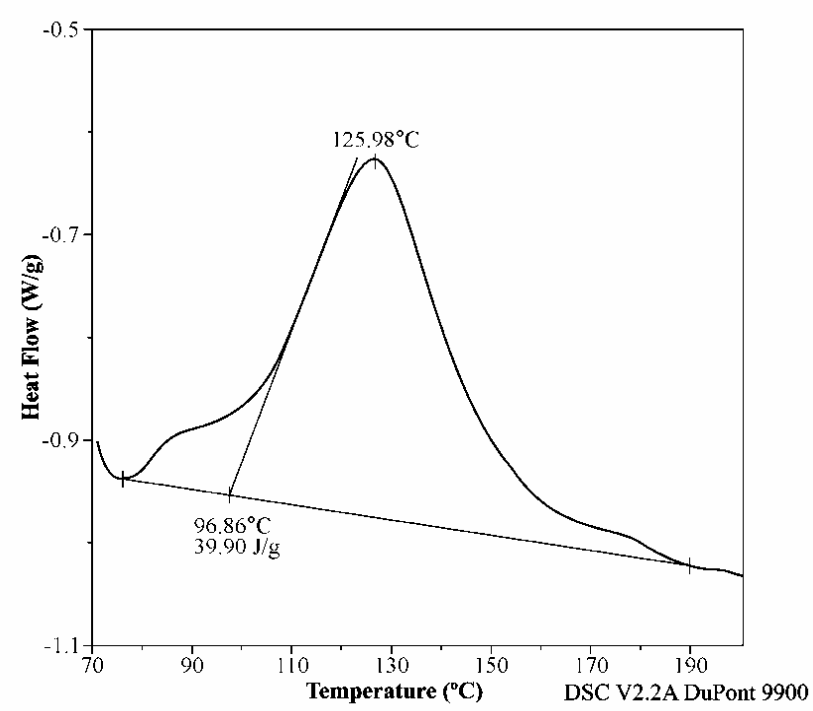

Fig. 1. DSC curve for mixture Epikote-828-thiokol taken at a ratio of 100:40

In order to determine the optimal conditions for the alignment (temperature and time) of the ER Epikote-828 with thiokol, the dependence of the adhesion shear strength $\left(\tau_{\mathrm{sh}}\right)$ on the mixing time of the components at different temperatures was studied. As follows from Fig. 2, the effect of increasing $\tau_{\mathrm{sh}}$ is observed in a wide temperature range $\left(90-180^{\circ} \mathrm{C}\right)$ of mixing and corresponds to the temperature range

Table 1

Thermal-physical properties of epoxy-thiokol mixtures

\begin{tabular}{c|c|c|c}
\hline $\begin{array}{c}\text { Composition of mixture, } \\
\text { weight parts }\end{array}$ & $\begin{array}{c}\text { Heat effect of } \\
\text { reaction, } \mathrm{Q}, \mathrm{J} \mathrm{g}^{-1}\end{array}$ & $\begin{array}{c}\text { Temperature of beginning } \\
\text { reaction, } \mathrm{T}_{\mathrm{b}},{ }^{0} \mathrm{C}\end{array}$ & $\begin{array}{c}\text { Temperature of maximal } \\
\text { rate of reaction, } \mathrm{T}_{\mathrm{m}},{ }^{0} \mathrm{C}\end{array}$ \\
\hline $\begin{array}{c}\text { Epikote-828 - } 100 \\
\text { thiokol }-40\end{array}$ & 38.9 & 96.86 & 125.98 \\
\hline $\begin{array}{c}\text { Epikote-828 }-100 \\
\text { thiokol - } 100\end{array}$ & 36.61 & 102.49 & 131.82 \\
\hline $\begin{array}{c}\text { Epikote-828 - 100 } \\
\text { thiokol - } 200\end{array}$ & 38.63 & 85.73 & 127.19 \\
\hline
\end{tabular}

K.M. Sukhyy, E.A. Belyanovskaya, A.N. Nosova, M.K. Sukhyy, V.P. Kryshen, Y. Huang, Yu. Kocherhin, T. Hryhorenko 
of the chemical reaction of SH- with epoxy groups (Fig. 1). In this case, at low mixing temperatures, a monotonic increase in $\tau_{\mathrm{sh}}$ is observed with reaching the saturation point the earlier, the higher the temperature is. At temperatures $\geq 160^{\circ} \mathrm{C}$, the maximum value of $\tau_{\mathrm{sh}}$ is reached after $2-3$ hours, after which a slight decrease in the adhesive strength occurs, which is possibly due to thermal destructive processes at elevated mixing temperatures. Based on the results obtained, for further studies, the products of the preliminary thioetherification reaction (PRTE) obtained at $160^{\circ} \mathrm{C}$ for $2 \mathrm{~h}$ with thorough stirring of the ER with thiokol were used.

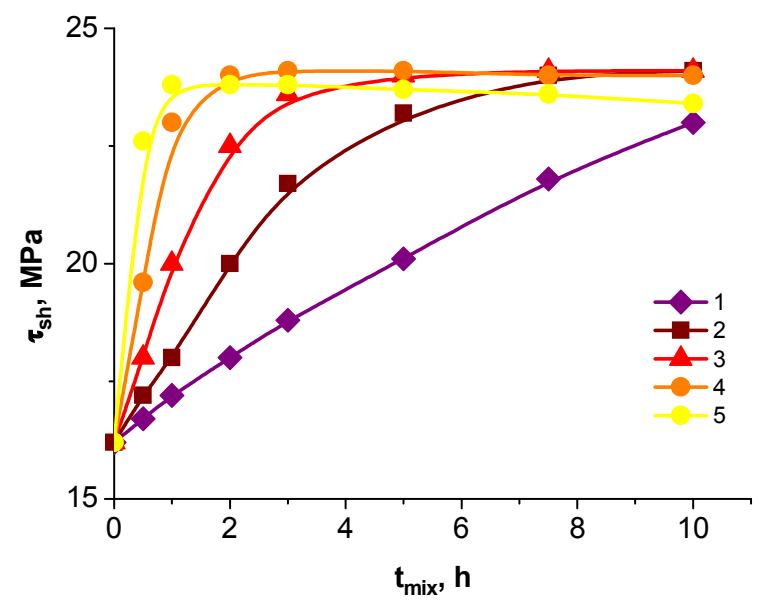

Fig. 2. Dependences of shear strength $\left(\tau_{\mathrm{sh}}\right)$ on mixing time $\left(\mathrm{t}_{\text {mix }}\right)$ of mixture of epoxy oligomer and thiokol (100:60 weight parts) at various temperatures of carrying out PRTE: $90^{\circ} \mathrm{C}(1)$, $120^{\circ} \mathrm{C}(2), 150^{\circ} \mathrm{C} \mathrm{(3)}, 160^{\circ} \mathrm{C} \mathrm{(4),} 180^{\circ} \mathrm{C}(5)$

Comparative studies of mechanical mixtures (MM) and PRTE products exhibit (Fig. 3) that for both systems there are extreme dependences of $\tau_{\mathrm{sh}}$ on the concentration (C) of thiokol, and the maximum values of adhesion strength are shown at the same rubber content ( $\sim 60$ weight parts). In the all studied concentration range, the value of $\tau_{\mathrm{sh}}$ for the PRTE product exceeds the values of the adhesion strength for the MM. Moreover, as can be seen from Fig. 4, the absolute increment of adhesion strength $\Delta \tau_{\mathrm{sh}}=\tau_{\mathrm{PRTE}}-\tau_{\mathrm{MM}}$ has the form of a dependence consisting of two main sections. In the first (initial) section, $\Delta \tau_{\mathrm{sh}}$ increases very rapidly with an increase in thiokol content (up to $\sim 40$ weight parts) with an average rate of about $170 \mathrm{kPa} /$ weight parts. Then, in the transition section in the range of 40-60 weight parts, the growth of $\Delta \tau_{\mathrm{sh}}$ slows down, although it is still quite noticeable ( $\sim 45 \mathrm{kPa} /$ weight part). At $\mathrm{C} \geq 60$ weight parts (in the second section), $\Delta \tau_{\text {sh }}$ changes

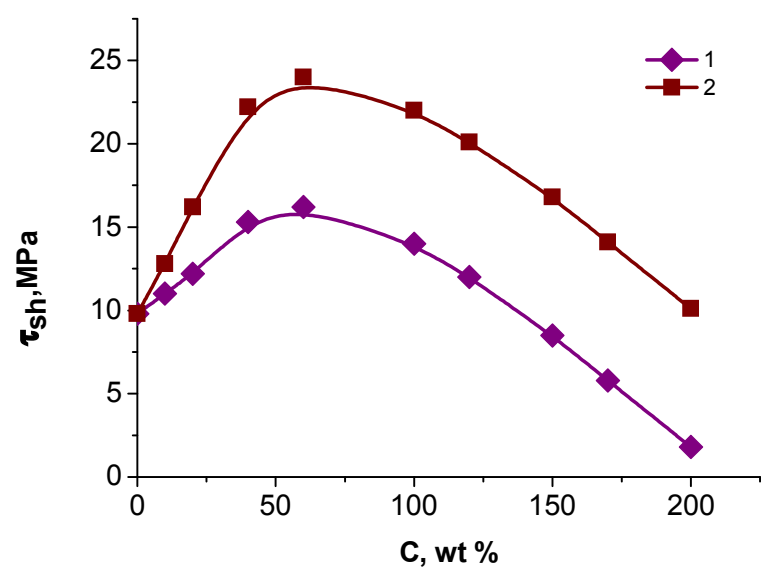

Fig. 3. Dependences of shear strength $\left(\tau_{\mathrm{sh}}\right)$ on concentration of thiokol when mechanically mixed (1) and product of preliminarily reaction of thioetherification used (2)

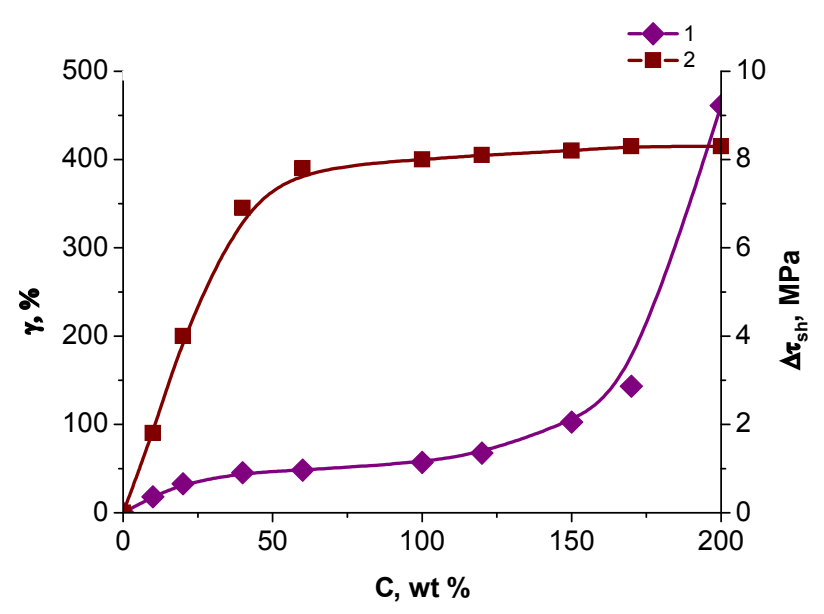

Fig. 4. Dependences of relative $\gamma(1)$ and absolute $\Delta \tau_{\text {sh }}$ (2) gradient of adhesive strength of epoxy composite on concentration of thiokol

very little, the increment of $\tau_{\text {sh }}$ being only $3 \mathrm{kPa} /$ weight part.

Three characteristic sections can be distinguished on the dependence of the relative increment of adhesion strength $\gamma=\tau_{\mathrm{PRTE}} / \tau_{\mathrm{MM}}$. On the first, corresponding to the content of rubber from 0 to 40 mass part, $\gamma$ grows rapidly with a rate of $1.12 \%$ /weight part; in the second section $(40<\mathrm{C}<120$ weight part), $\gamma$ increases insignificantly $(0.25 \%$ per weight part), i.e. 4.5 times slower than in the initial section. Finally, in the third section $(\mathrm{C} \geq 120$ weight parts), $\gamma$ grows again at a very high rate $(4.95 \%$ per a weight part), i.e. it surpasses the initial section in 4.4 times.

The cohesive strength $\sigma_{t}$ as a result of the PRTE changes to a much lesser extent relative to the MM than the adhesive strength (Fig. 5,a). At the same time, with small additions of rubber (10 and $15 \mathrm{wt}$. 
parts, respectively, for the mechanical mixture and PRTE), small maxima are observed on the $\sigma_{t}$ vs. C dependences, after which the strength decreases rather quickly with an increase in the concentration of the modifier. In this case, as in the case of the dependence $\tau_{\text {sh }}$ vs. C, the value of $\sigma_{t}$ for the products of PRTE is higher than for MM in the entire studied range of thiokol concentrations. Deformation at rupture increases quite noticeably after PRTE (Fig. 5,b). The effect is especially pronounced at rubber concentrations greater than $100 \mathrm{wt}$. parts. Thus, with an increase in the content of the modifier from 0 to 100 weight parts, $\varepsilon_{\mathrm{s}}$ increases by 1.69 and 2.75 times for MM and PRTE, respectively. In the range of thiokol concentrations from 100 to $200 \mathrm{wt}$. parts, the corresponding growth of $\varepsilon_{\mathrm{s}}$ is 3.69 and 4.55 times. Due to this, even with a small gain in strength, the parameter $A_{p}$, which characterizes the work of destruction of the material, increases very significantly (Fig. 6,a). At the same time, an increase in $A_{p}$ is not observed for MM (Fig. 6,a, curve 1). As a result of PRTE, the modulus of elasticity $\mathrm{E}$

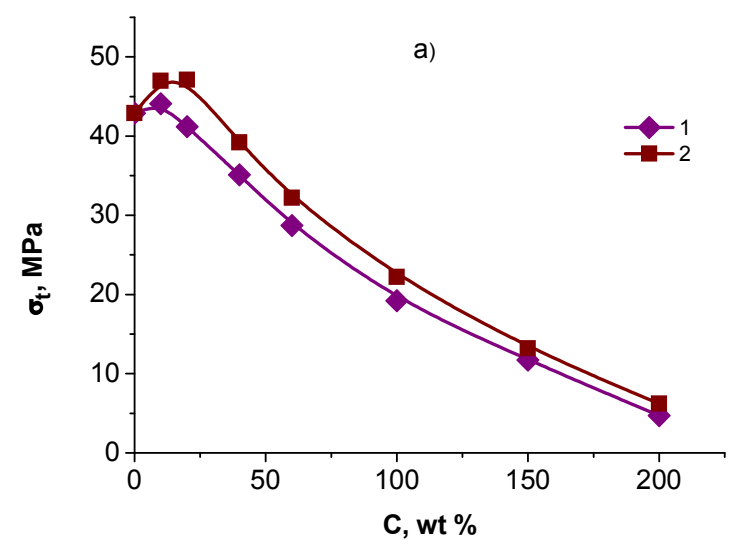

(Fig. 6,b) of the composite slightly increases, while water absorption (Fig. 7,a) and abrasion (Fig. 7,b), on the contrary, decrease. In this case, the modulus $\mathrm{E}$ of the composition after reaching a small maximum at $\mathrm{C}=10$ wt. parts decreases rather quickly with an increase in thiokol content up to $40 \mathrm{wt}$. parts. Further in the range $40<C<100 \mathrm{wt}$. parts, the plateau zone appears on the concentration dependences of $\mathrm{E}$, after which the magnitude of the modulus decreases again. Parameters W and I almost linearly increase with increasing $\mathrm{C}$, which indicates a decrease in their water and wear resistance. After the heat treatment, the decrease in I for MM is somewhat larger than for the PRTE product. This may be due to the fact that, in addition to an increase in the density of the chemical network because of additional hardening of the epoxy matrix at an elevated temperature, the thioetherification reaction also takes place in the composite based on MM.

The concentration dependence of $\varepsilon_{\mathrm{s}}$ is well correlated with the dependence of the molecular weight $\mathbf{M}_{\mathrm{c}}$ on the thiokol content (Fig. 8,a). With

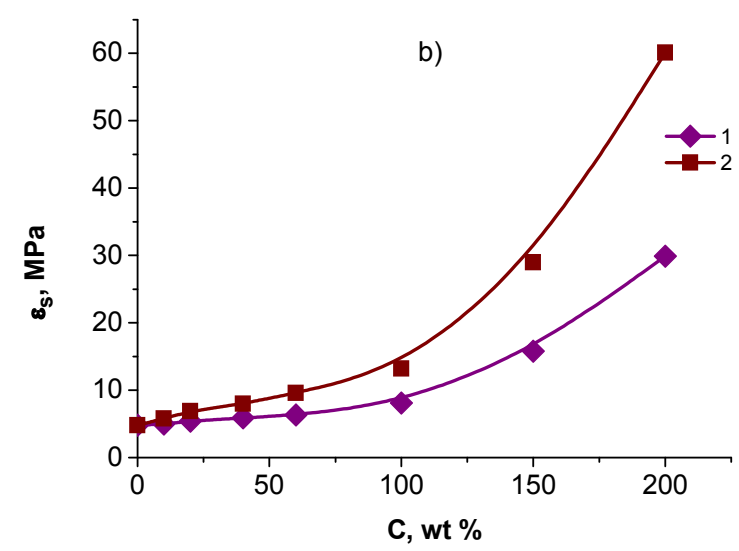

Fig. 5. Dependences of tensile strength (a) and deformation at rupture (b) on thiokol concentration for film samples based on mechanical mixture (1) and products of thioetherification reaction (2). The samples have been hardened by mode I
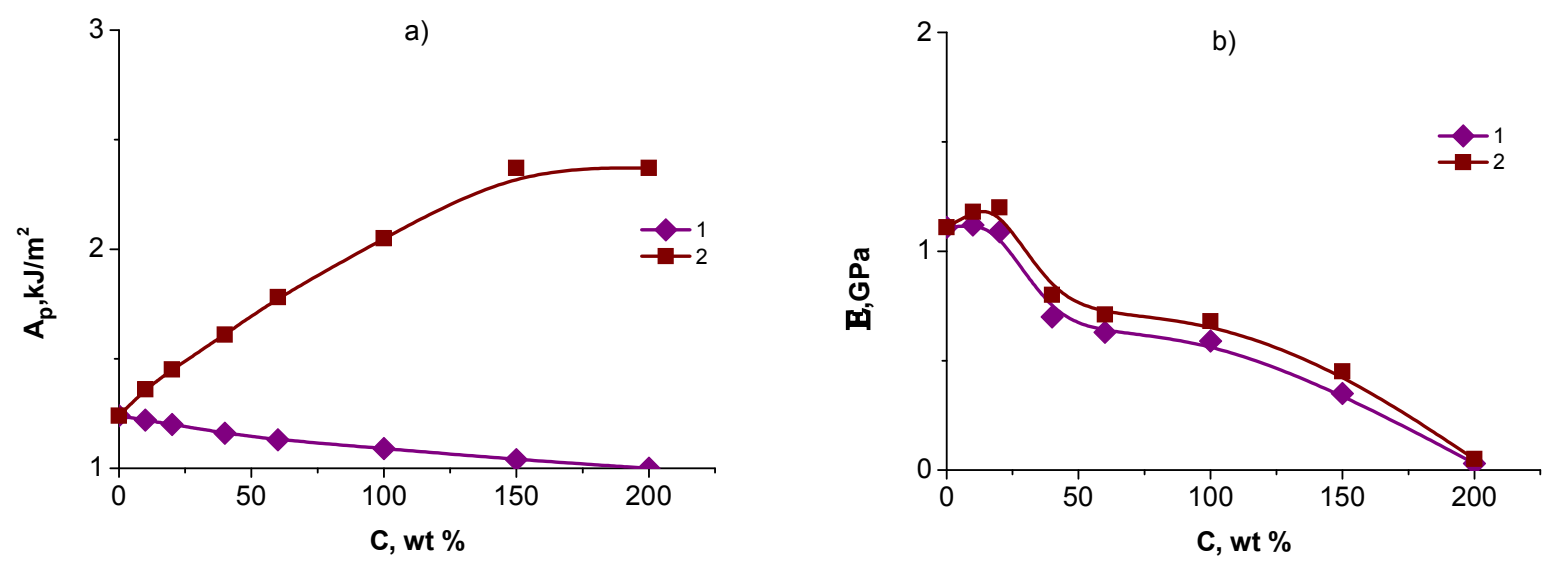

Fig. 6. Dependences of work of destruction (a) and elastic modulus (b) on thiokol concentration for filmy samples based on mechanical mixture (1) and products of thioetherification reaction (2). The samples have been hardened by mode I

K.M. Sukhyy, E.A. Belyanovskaya, A.N. Nosova, M.K. Sukhyy, V.P. Kryshen, Y. Huang, Yu. Kocherhin, T. Hryhorenko 

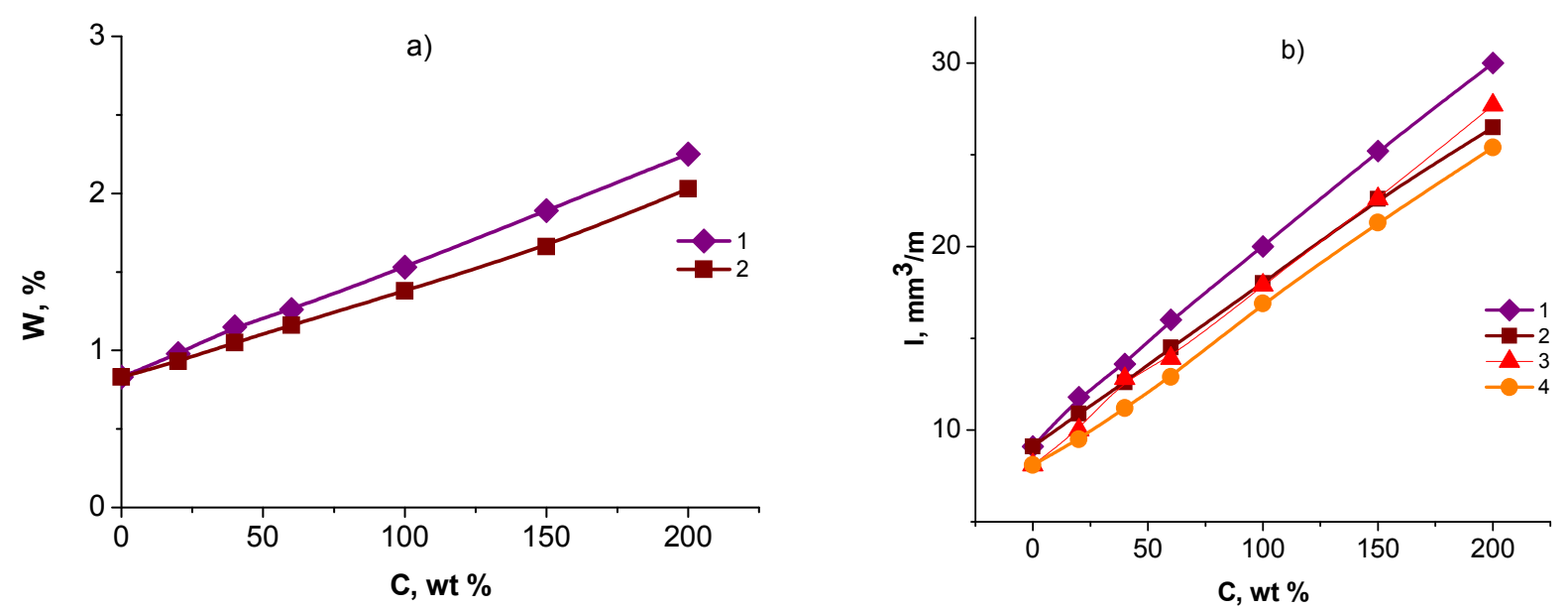

Fig. 7. Dependences of water uptake (a) and abrasion (b) on thiokol concentration for film samples based on mechanical mixture $(1,3)$ and products of thioetherification reaction $(2,4)$. The samples have been hardened by modes I $(1,2)$ and II $(3,4)$
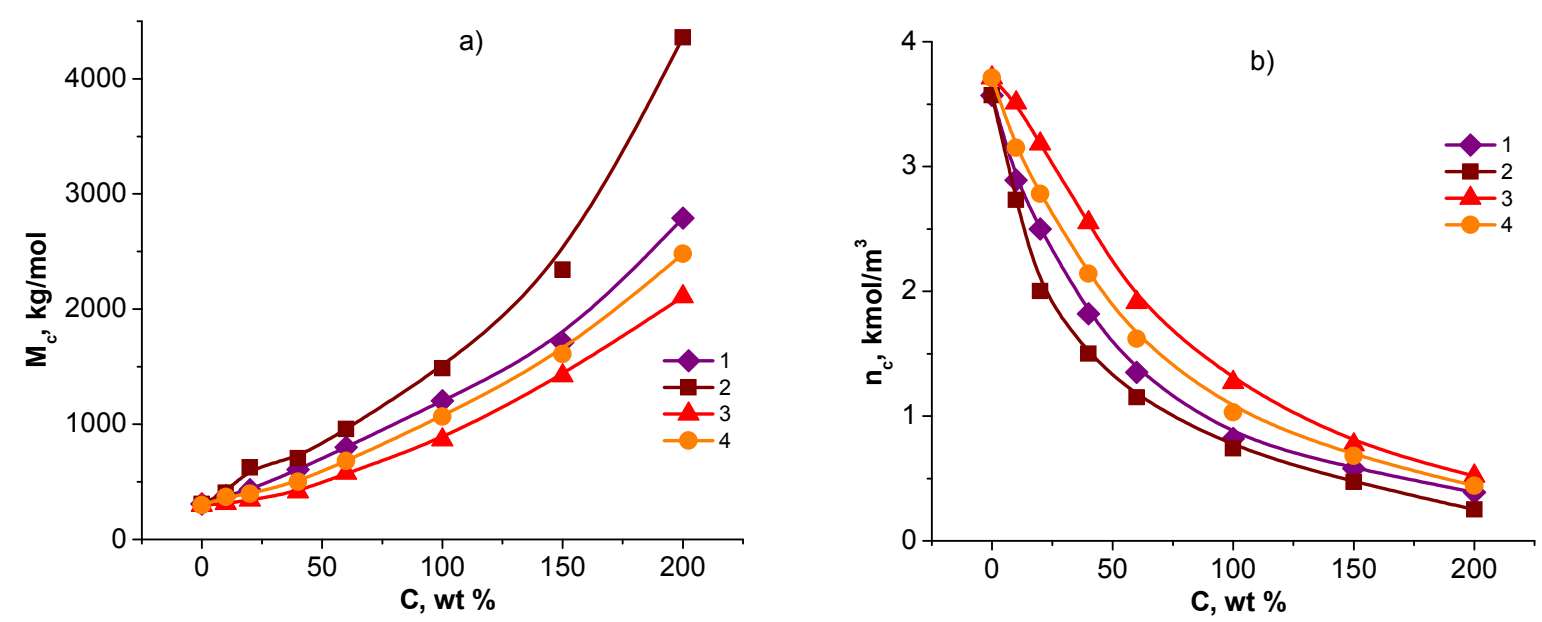

Fig. 8. Dependences of $M_{c}$ (a) and $n_{c}$ (b) on thiokol concentration for film samples based on mechanical mixture $(1,3)$ and products of thioetherification reaction $(2,4)$. The samples have been hardened by modes I $(1,2)$ and II $(3,4)$

an increase in the concentration of the rubber $\mathrm{M}_{\mathrm{c}}$ of the composition increases, and accordingly the density of the nodes of the chemical network $n_{c}$ decreases (Fig. 8,b), i.e., the flexibility of the macromolecular chain between the crosslinking sites increases. As a result, the modified samples are more enabled to develop deformation as evidenced by the data in Fig. 5,b.

It should be noted that the samples based on PRTE have a lower density $\rho$ as compared to MM (Fig. 9); a higher density $\rho$ corresponds to a lower molecular weight $\mathbf{M}_{c}$ (and, accordingly, a higher density of chemical network nodes $n_{c}$ ). In this case, the density of polymers based on MM is higher than the calculated curve obtained taking into account the additive contribution of the individual components of the mixture. For the products based on PRTE, the values of $\rho$ lie below the calculated curve. With an increase in the concentration of

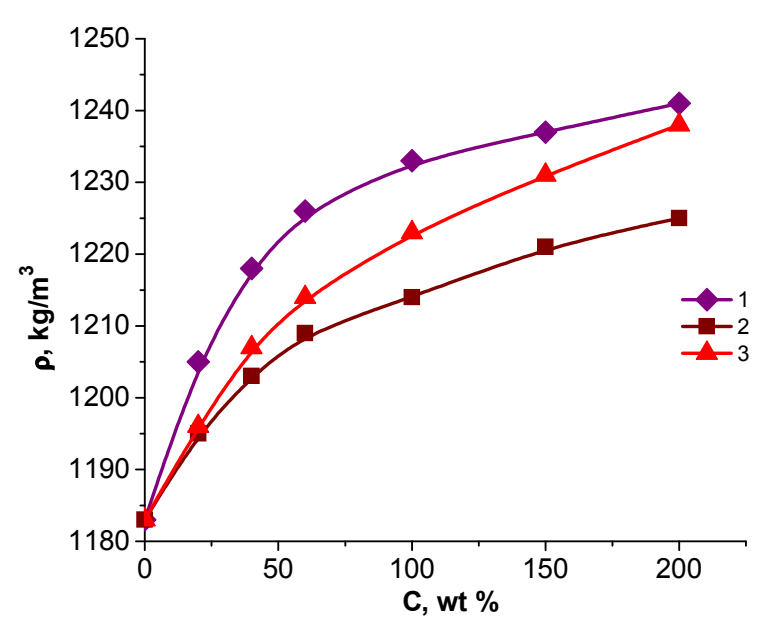

Fig. 9. Dependences of density ( $\rho$ ) on thiokol concentration (C) for mechanical mixtures (1) and products of thioetherification reaction (2); 3 - calculated curve 

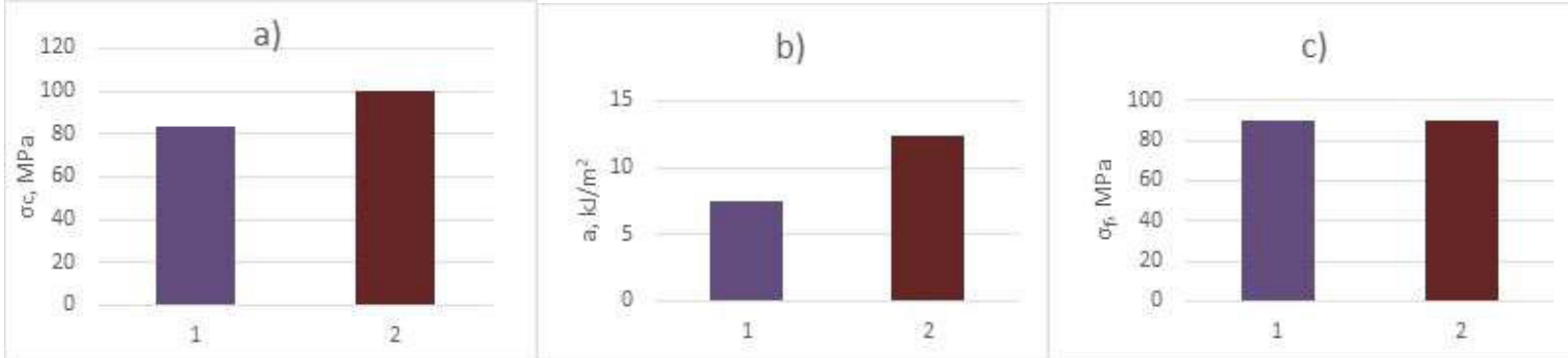

Fig. 10. Dependences of compression strength (a), specific impact viscosity (b) and bending strength (c) on the method of involving the modifier for mechanical mixture (1) and product of reaction of thioetherification (2), containing 20 weight parts of thiokol per $100 \mathrm{wt}$. parts of epoxide resin. The samples have been hardened by mode I. The samples have been hardened by mode I

thiokol, the calculated curve moves away more and more from the dependence $\rho$ vs. C for PRTE and, conversely, approaches the analogous dependence for MM. Nevertheless, even at $\mathrm{C}=200 \mathrm{wt}$. parts, where the difference in the values of the calculated density and experimentally measured for PRTE is maximum, the difference in their values does not exceed $1.05 \%$.

The results of the study also exhibit (Fig. 10) that after carrying out the PRTE, the compressive strength of the samples increases by about $15 \%$, the specific impact strength increases more significantly (by $75 \%$ ), and the flexural strength practically does not change.

Referring again to Fig. 2, it should be noted that due to the performance of the PRTE, it is possible to significantly increase the adhesive strength of epoxy-thiokol mixtures. As a result, a composition based on PRTE containing $20 \mathrm{wt}$. parts including thiokol, provides the same level of strength of adhesive joints as a mechanical mixture, but containing $60 \mathrm{wt}$. parts of rubber.

This testifies to the economic feasibility of using PRTE products. Comparative characteristics of epoxy composites based on a base (unmodified) resin as well as a mechanical mixture and a PRTE product containing $20 \mathrm{wt}$. including thiokol are given in Table 2.

Table 2

Influence of methods of thiokol appending on the properties of epoxy polymers

\begin{tabular}{l|c|c|c}
\hline \multirow{2}{*}{\multicolumn{1}{c|}{ Properties }} & \multicolumn{3}{|c}{ Rubber content } \\
\cline { 2 - 4 } & $\begin{array}{l}0 \text { (Basic } \\
\text { sample) }\end{array}$ & \multicolumn{2}{|c}{20} \\
\hline Shear strength, $\tau_{\mathrm{sh}}, \mathrm{MPa}$ & 9.8 & 12.3 & 16.2 \\
\hline Tensile strength, $\sigma_{\mathrm{t}}, \mathrm{MPa}$ & 42.8 & 40.4 & 47.5 \\
\hline Elastic modulus, $\mathrm{E}, \mathrm{GPa}$ & 1.11 & 0.99 & 1.20 \\
\hline Work of destruction, $\mathrm{A}_{\mathrm{p}}, \mathrm{kJ} \mathrm{m}^{-2}$ & 1.24 & 1.20 & 1.48 \\
\hline Specific impact viscosity, $\mathrm{a}, \mathrm{kJ} \mathrm{m}^{-2}$ & 3.8 & 7.8 & 13.0 \\
\hline
\end{tabular}

It can be seen that, in all parameters, materials based on PRTE are significantly superior to MM. Thus, in terms of $\tau_{\text {sh }}$, the effect is $31.7 \%$, and specific impact strength is $66.7 \%$. Compared to the base sample, the increase in parameters is even greater: for $\tau_{\mathrm{sh}}$ it equals $65.3 \%$, for specific impact strength it is $242 \%$.

Thus, the results of the study unambiguously indicate that the preliminary thioetherification reaction provides an increase in the deformationstrength and adhesive properties of mixtures of epoxy resins with thiokols. The effect of increasing the shear strength of adhesive joints and impact resistance is especially noticeable when the compositions are hardened without heat supply.

\section{Conclusions}

A method for producing composite materials with improved adhesive and physical-mechanical properties based on epoxy-thiokol mixtures has been theoretically and experimentally substantiated. The effect is achieved due to the use in the composition of the composite as a resin part of the products of the preliminary reaction of thioetherification, obtained as a result of the interaction of oxirane cycles of epoxy resins with mercaptan groups of thiocol.

The temperature range $\left(90-180^{\circ} \mathrm{C}\right)$ of the thioetherification reaction was determined by the method of differential scanning calorimetry. The optimum temperature $\left(160^{\circ} \mathrm{C}\right)$ and the duration of the preliminary thioetherification reaction ( 2 hours), which provide the maximal level of adhesive strength and physical and mechanical properties, have been determined.

The composites based on the products of the thioetherification reaction are shown to significantly surpass analogs based on mechanical mixtures of epoxy resin and thiokol in terms of impact strength (1.72 times), static and dynamic adhesive strength (1.35 and 1.90 times, respectively).

Thus, the results of the study unambiguously 
indicate that carrying out a preliminary thioetherification reaction provides an increase in the deformation strength and adhesion properties of mixtures of epoxy resins with thiokols. The effect of increasing the shear strength of adhesive joints and impact resistance is especially noticeable when the compositions are hardened without external heat supply.

\section{REFERENCES}

1. Kochergin Yu.S., Kulik T.A., Grigorenko T.I. Specialpurpose epoxy adhesives // Polymer Sci. Ser. C. - 2007. - Vol.49. - No. 1. - P.17-21.

2. Эпоксидные олигомеры и клеевые композиции / Ю.С. Зайцев, Ю.С. Кочергин, М.К. Пактер, Р.В Кучер. К.: Наук. думка, 1990. - 200 с.

3. The study of properties of composite adsorptive materials «silica gel - crystalline hydrate» for heat storage devices / Sukhyy K., Belyanovskaya E., Kovalenko V., Kotok V., Sukhyy M., Kolomiyets E., Gubynskyi M., Yeromin O., Prokopenko O. // East.-Eur. J. Enterprise Technol. - 2018. - Vol.91. - No. 1. P.52-58.

4. Performance of an adsorptive heat-moisture regenerator based on silica gel-sodium sulphate / Belyanovskaya E., Rimar M., Lytovchenko R.D., Variny M., Sukhyy K.M., Yeromin O.O., Sykhyy M.P., Prokopenko E.M., Sukha I.V., Gubinskyi M.V., Kizek J. // Sustainability. - 2020. - Vol.12. - No. 14. - Article No. 5611 .

5. Kabat O., Sytar V., Sukhyy K. Antifrictional polymer composites based on aromatic polyamide and carbon black // Chem. Chem. Technol. - 2018. - Vol.12. - No. 3. - P.326-330.

6. Role of ionene in composition of porous structure of template-synthesized silicas / Berezovska I.S., Yanishpolskii V.V., Tertykh V.A., Burmistr M.V., Sukhyy K.M. // J. Therm. Anal. Calorim. - 2006. - Vol.86. - No. 1. - P.93-96.

7. Кочергин Ю.С., Кулик Т.А., Григоренко Т.И. Клеи на основе модифицированных каучуками эпоксидных смол // Пласт. массы. - 2005. - № 12. - С.5-9.

8. Эпоксидные клеи со специальным комплексом свойств / Ю.С. Кочергин, Т.И. Григоренко, В.В. Шологон, Д.П. Лойко // Вопросы химии и хим. технол. -2007 . - № 5. - С.92-98.

9. Резины, герметики и огнетеплозащитные материалы / О.А. Елисеев, И.С. Наумов, Д.Н. Смирнов, Я.А. Брык // Авиационные материалы и технол. - 2017. - № 5. C.437-451.
10. Брык А.Я., Елисеев О.А., Смирнов Д.Н. Защита от коррозии магниевых сплавов полисульфидными герметиками // Труды ВИАМ. - 2017. - № 10(58). - С.90-96.

11. Исследование влияния атмосферных факторов на основные характеристики герметизирующих материалов авиационного назначения / А.М. Чайкун, М.А. Венедиктова, Д.Н. Смирнов, Д.М. Герасимов // Труды ВИАМ. - 2019. - № 2(74). - С.58-67.

12. Pyrikov A.V., Loiko D.P., Kochergin Yu.S. Modification of epoxy resins with liquid polysulfide and carboxylated butadiene rubbers // Polym. Sci. Ser. D. - 2010. - Vol.3. - No. 3. P.185-189.

13. Малкин А.Я., Аскадский А.А., Коврига В.В. Методы измерения механических свойств полимеров. - М. Химия, 1978. $-336 \mathrm{c}$.

Received 17.02.2021

\section{ВЛАСТИВОСТІ ЕПОКСИДНО-ТІОКОЛОВИХ МАТЕРІАЛІВ НА ОСНОВІ ПРОДУКТІВ ПОПЕРЕДНЬОЇ РЕАКЦIÏ ТІОЕТЕРІФІКАЦІЇ}

К.М. Сухий, О.А. Бєляновська, А.М. Носова, М.К. Сухий, В.П. Кришень, Ю. Хуанг, Ю.С. Кочергін, Т.І. Григоренко

3 метою покращення адгезійних та фізико-механічних властивостей епоксидно-тіоколових композицій холодного отвердження, запропоновано до введення твердника проводити реакцію взаємодії меркаптанових груп тіоколу і оксиранових циклів епоксидної смоли при підвищеній температурі, а потім використовувати продукт цієї реакції тіоетеріфікації для отвердження при кімнатній температурі. Методом диференціальної скануючої калориметрії визначено температурний інтервал $\left(90-180^{\circ} \mathrm{C}\right)$ протікання реакції тіоетеріфікації. Визначено оптимальні температура $\left(160^{\circ} \mathrm{C}\right) \mathrm{i}$ тривалість проведення (2 години) попередньої реакції тіоетеріфікаціi, що забезпечують максимальний рівень адгезійної міцності і фізико-механічних властивостей. Показано, що композиційні матеріали на основі продуктів реакції тіоетеріфікаціi істотно перевершують аналоги на основі механічних сумішей епоксидної смоли і тіоколу за величиною когезійної і адгезійної міцності, деформаційної здатності, роботи руйнування і питомої ударної в'язкості. Особливо суттєво підвищується ударостійкість і міцність на зсув клейових з'єднань під час отвердження композицій без підведення тепла ззовні.

Ключові слова: епоксидна смола; тіокол; реакція тіоетеріфікаціі; адгезійні і когезійні властивості; механічна суміш; диференціальна скануюча калориметрія. 


\section{PROPERTIES OF EPOXY-THIOKOL MATERIALS BASED ON THE PRODUCTS OF THE PRELIMINARY REACTION OF THIOETHERIFICATION}

\section{K.M. Sukhyy ${ }^{a}$, E.A. Belyanovskaya ${ }^{a}$, A.N. Nosova ${ }^{a,}$, M.K. Sukhyy ${ }^{a}$, V.P. Kryshen ${ }^{b}$, Y. Huang ${ }^{c}$, Yu. Kocherhin ${ }^{c}$, T. Hryhorenko ${ }^{c}$}

a Ukrainian State University of Chemical Technology, Dnipro, Ukraine

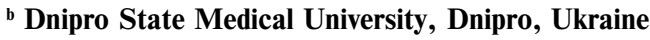

c Harbin Institute of Technology, Harbin, People's Republic of China

* e-mail: ikichemisty@gmail.com

In order to improve the adhesive and physical-mechanical properties of epoxy-thiocol compositions cured without heat treatment, we propose to carry out the reaction of interaction between thiokol mercaptan groups and oxirane cycles of epoxy resin at an elevated temperature before introducing a curing agent, and then use the product of this thioetherification reaction for curing at room temperature. The temperature range of the thioetherification reaction $\left(90-180^{\circ} \mathrm{C}\right)$ was determined by the method of differential scanning calorimetry. The optimal temperature $\left(160^{\circ} \mathrm{C}\right)$ and duration of the preliminary thioetherification reaction (2 hours) were determined, which ensure the maximum level of adhesive strength and physicalmechanical properties. It was shown that composite materials based on the products of the thioetherification reaction significantly outperform analogs based on mechanical mixtures of epoxy resin and thiokol in terms of cohesive and adhesive strength, deformation capacity, fracture work and specific impact strength. The impact resistance and shear strength of adhesive joints are especially significantly increased during the curing of the compositions without external heat supply.

Keywords: epoxy resin; thiokol; thioetherification reaction; adhesive and cohesive properties; mechanical mixture; differential scanning calorimetry.

\section{REFERENCES}

1. Kochergin YS, Kulik TA, Grigorenko TI. Specialpurpose epoxy adhesives. Polym Sci Ser C. 2007; 49: 17-21. doi: 10.1134/S1811238207010043.

2. Zaitsev YS, Kochergin YuS, Pakter MK, Kucher RV. Epoksidnye oligomery $i$ kleevye kompozitsii [Epoxy oligomers and adhesive compositions]. Kyiv: Naukova Dumka; 1990. 200 p. (in Russian).

3. Sukhyy K, Belyanovskaya E, Kovalenko V, Kotok V, Sukhyy M, Kolomiyets E, et al. The study of properties of composite adsorptive materials «silica gel - crystalline hydrate» for heat storage devices. East Eur J Enterprise Technol. 2018; 91(1): 52-58. doi: 10.15587/1729-4061.2018.123896.
4. Belyanovskaya E, Rimar M, Lytovchenko RD, Variny M, Sukhyy KM, Yeromin OO, et al. Performance of an adsorptive heat-moisture regenerator based on silica gel-sodium sulphate. Sustainability. 2020; 12(14): 5611. doi: 10.3390/su12145611.

5. Kabat O, Sytar V, Sukhyy K. Antifrictional polymer composites based on aromatic polyamide and carbon black. Chem Chem Technol. 2018; 12(3): 326-330.

doi: $10.23939 /$ chcht 12.03 .326 .

6. Berezovska IS, Yanishpolskii VV, Tertykh VA, Burmistr MV, Sukhyy KM. Role of ionene in composition of porous structure of template-synthesized silicas. J Therm Anal Calorim. 2006; 86: 93-96. doi: 10.1007/s10973-006-7579-1.

7. Kochergin YS, Kulik TA, Grigorenko TI. Klei na osnove modifitsirovannykh kauchukami epoksidnykh smol [Adhesives based on rubber-modified epoxy resins]. Plasticheskie Massy. 2005; 12: 5-9. (in Russian).

8. Kochergin YS, Grigorenko TI, Shologon VV, Loiko DP. Epoksidnye klei so spetsial'nym kompleksom svoistv [Epoxy adhesives with a special set of properties]. Voprosy Khimii $i$ Khimicheskoi Tekhnologii. 2007; (5): 92-98. (in Russian).

9. Eliseev OA, Naumov IS, Smirnov DN, Bryk YA. Reziny, germetiki i ogneteplozashchitnye materialy [Rubber, sealants and fire and heat protection materials]. Aviatsionnye Materialy $i$ Tekhnologii. 2017; (5): 437-451. (in Russian). doi: 10.18577/2071-9140-2017-0-S-437-451.

10. Bryk AY, Eliseev OA, Smirnov DN. Zashchita ot korrozii magnievykh splavov polisul'fidnymi germetikami [Corrosion protection of magnesium alloys with polysulfide sealants]. Trudy VIAM. 2017; 10(58): 90-96. (in Russian). doi: 10.18577/2307-6046-2017-0-10-10-10.

11. Chaykun AM, Venediktova MA, Smirnov DN, Gerasimov DM. Issledovanie vliyaniya atmosfernykh faktorov na osnovnye kharakteristiki germetiziruyushchikh materialov aviatsionnogo naznacheniya [Investigation of the influence of atmospheric factors on the main characteristics of aviation sealing materials]. Trudy VIAM. 2019; 2(74): 58-67. (in Russian). doi: 10.18577/2307-6046-2019-0-2-58-67.

12. Pyrikov AV, Loiko DP, Kochergin YS. Modification of epoxy resins with liquid polysulfide and carboxylated butadiene rubbers. Polym Sci Ser D. 2010; 3: 185-189.

doi: 10.1134/S1995421210030068.

13. Malkin AY, Askadsky AA, Kovriga VV. Metody izmereniya mekhanicheskikh svoystv polimerov [Methods for measuring the mechanical properties of polymers]. Moscow: Khimiya; 1978. 336 p. (in Russian). 